\title{
Brief communication: A submarine wall protecting the Amundsen Sea intensifies melting of neighboring ice shelves
}

\author{
Özgür Gürses ${ }^{1}$, Vanessa Kolatschek ${ }^{1}$, Qiang Wang ${ }^{1}$, and Christian Bernd Rodehacke ${ }^{1,2}$ \\ ${ }^{1}$ Alfred-Wegener-Institut Helmholtz-Zentrum für Polar- und Meeresforschung, 27570 Bremerhaven, Germany \\ ${ }^{2}$ Danish Meteorological Institute, Copenhagen $\varnothing, 2100$, Denmark \\ Correspondence: Christian B. Rodehacke (christian.rodehacke@awi.de)
}

Received: 11 February 2019 - Discussion started: 15 March 2019

Revised: 22 July 2019 - Accepted: 14 August 2019 - Published: 6 September 2019

\begin{abstract}
Disintegration of ice shelves in the Amundsen Sea, in front of the West Antarctic Ice Sheet, has the potential to cause sea level rise by inducing an acceleration of ice discharge from upstream grounded ice. Moore et al. (2018) proposed that using a submarine wall to block the penetration of warm water into the subsurface cavities of these ice shelves could reduce this risk. We use a global sea ice-ocean model to show that a wall shielding the Amundsen Sea below $350 \mathrm{~m}$ depth successfully suppresses the inflow of warm water and reduces ice shelf melting. However, these warm water masses get redirected towards neighboring ice shelves, which reduces the net effectiveness of the wall. The ice loss is reduced by $10 \%$, integrated over the entire Antarctic continent.
\end{abstract}

\section{Introduction}

One of the consequences of the warming of Earth's climate is sea level rise (Vaughan et al., 2013). Sea level rise will impact coastal societies and economic activity in these areas. Currently, the main contributors to rising global mean sea level are the thermal expansion of the world's ocean, the mass losses emanating from the Greenland Ice Sheet, and the worldwide recession of mountain glaciers and ice caps (Chen et al., 2017; Rietbroek et al., 2016; Shepherd et al., 2012). The remaining smaller sources are continental groundwater depletion (Wada et al., 2012) and the Antarctic Ice Sheet (King et al., 2012; Rietbroek et al., 2016; Shepherd et al., 2012); though Antarctica's sea level contribution has accelerated in recent decades (King et al., 2012; Rietbroek et al., 2016; Rignot et al., 2011).
In Antarctica, remotely sensed, modeled and paleoclimatological proxy data indicate that the highest potential sea level contribution will come from the West Antarctic Ice Sheet (Bamber et al., 2009; Golledge et al., 2013; Joughin and Alley, 2011; Pollard and DeConto, 2009; Sutter et al., 2016), particularly from the Amundsen Sea sector, where the progressive thinning of its ice shelves over the last 2.5 decades has greatly enhanced rates of ice mass loss emanating from this sector (Pritchard et al., 2012; Rignot et al., 2014; Shepherd et al., 2018). Here ice shelves currently prevent unrestricted flow of ice streams into the ocean. Here, warm high-salinity Circumpolar Deep Water (CDW) has been observed to flow onto the continental shelf and flood the cavities underneath the Amundsen Sea sector's ice shelves, driving high rates of basal melting (Depoorter et al., 2013; Jacobs et al., 2011; Jenkins et al., 2018; Pritchard et al., 2012). Various processes control the flow of warm water masses (a body of ocean water with a common formation history and a defined range of tracers, such as temperature and salinity, is called water mass) predominately via glacially scoured submarine troughs (Bingham et al., 2012; Dutrieux et al., $2014)$ into the ice shelf cavities. It includes wind-driven Ekman transport, whereby variations in offshore wind stresses, also altered by local sea ice conditions (Kim et al., 2017), lift CDW onto the continental shelf (Dutrieux et al., 2014; Kim et al., 2017; Paolo et al., 2018; Schmidt et al., 2013). During its transport onto the continental shelf, the water mass is transformed into modified CDW (mCDW) by mixing with local, fresher on-shelf water masses (Webber et al., 2017, 2018). In the Amundsen Sea, decadal-scale changes in the draft and intensity of the CDW incursion onto the continental shelf - and ultimately the basal melting of the ice masses 
fringing this sector of Antarctica - have also been directly linked to changes in large-scale oceanic and atmospheric circulation, including the influence of El Niño-Southern Oscillation (ENSO)-induced atmospheric wave trains propagating towards this region from the central tropical Pacific Ocean (Dutrieux et al., 2014; Jenkins et al., 2018; Nakayama et al., 2018; Steig et al., 2012). These processes together drive the detected retreat of ice shelves in the Amundsen Sea through decadal oceanographic variability (Jenkins et al., 2018).

Since the West Antarctic Ice Sheet resides on retrogradesloping bedrock topography (Fretwell et al., 2013), it is inherently susceptible to marine ice sheet instability (Schoof, 2007; Weertman, 1974), whereby the reduced buttressing effect of thinning ice shelves triggers the retreat of upstream ice, leading to larger ice thickness at the grounding line the grounding line marks the transition from grounded ice to floating ice. This amplifies the ice flux across the new grounding line, which stretches and thins the ice further and ultimately triggers additional grounding line retreat. This sustained retreat accelerates the transport of grounded inland ice towards the ocean past the grounding line, where it directly contributes to sea level rise (by iceberg calving and ocean-driven melting).

Moore et al. (2018) proposed a targeted geoengineering project that could reduce the risk of this ice sheet instability by protecting the ice shelves from warm Circumpolar Deep Water via the erection of a submarine wall. Wolovick and Moore (2018) tested this idea with a simple flow line model (two-dimensional $x-z$ plane model) of Thwaites Glacier one of the largest contributors of ice discharge into the Amundsen Sea (Shepherd et al., 2018; Turner et al., 2017). In addition to the erection of a submarine wall, they imposed artificial pinning points to enhance the buttressing effect of ice shelves on grounded ice (cf. Moore et al., 2018). Both measures successfully reduced ice mass loss emanating from this sector of Antarctica (Wolovick and Moore, 2018).

In this paper, we investigate how a submarine wall shielding the Amundsen Sea embayment (Fig. 2a) reduces the basal melting rates of ice shelves flowing into the Amundsen Sea embayment. The warm water masses rejected by the wall enhance ice shelves west of the wall. These effects counteract the wall's purpose of mitigating sea level rise. In this study, we neglect feedbacks between changes of basal melting rates and advance or retreat of impacted ice shelves. We do not analyze how the wall hinders the exchange of nutrients and influences submarine biological processes.

\section{Model setup}

We use a global finite-element ocean model (FESOM; Wang et al., 2014) to test the effects of erecting a wall in front of the Amundsen Sea sector's ice shelves. The model has a variable horizontal resolution of (minimum $5 \mathrm{~km}$ ) around Antarctica and its adjacent ice shelf cavities and has 100

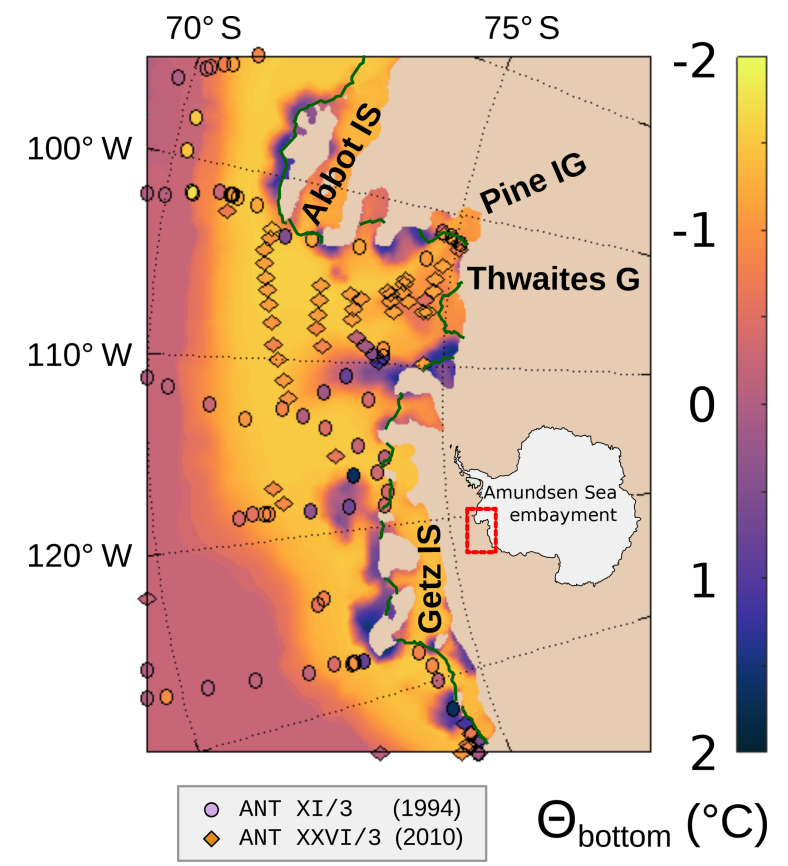

Figure 1. Modeled and observed seafloor ocean potential temperatures $\left(\theta_{\text {bottom }}\right)$ in the Amundsen Sea sector of West Antarctica. The plot shows the simulated mean ocean temperatures for the control run (CTRL, years 1948-2007), while circles (ANT XI/3; Miller and Grobe, 1996) or diamonds (ANT XXVI/3; Gohl, 2010) represent observed bottom temperatures taken in 1994 and 2010, respectively. The solid green lines follow shelf ice edges, and the inset shows the location of the area of interest as a red box.The following abbreviations are used: Abbot IS (Abbot Ice Shelf), Pine IG (Pine Island Glacier), Thwaites G (Thwaites Glacier) and Getz IS (Getz Ice Shelf).

vertical levels ( $z$ coordinate). The interaction between the ocean and static ice shelves occurs via the three-equation system that describes the flux of heat and fresh water between the ocean and ice shelf base through an exchangecontrolling boundary layer (Hellmer and Olbers, 1989; Holland and Jenkins, 1999). FESOM has proven its applicability for oceanographic studies of the Southern Ocean (Hellmer et al., 2012; Nakayama et al., 2014; Timmermann et al., 2012). While coarse-resolution models have been found to underestimate the ocean-induced basal melting of Antarctica's ice shelves (Naughten et al., 2018), our basal melting rates (Fig. 1b) are in reasonable agreement with recent observational estimates (Rignot et al., 2013). The model utilizes the ocean bathymetry, ice shelf geometry, and grounding line position data of RTOPO-1 (Timmermann et al., 2010). We use the CORE-II forcing for atmospheric conditions (Large and Yeager, 2008), covering the years 1948-2007, to drive the ocean model. This forcing period is run twice. The first full period is considered spin-up and, hence, we restrict our analysis to the last complete forcing period. 
Considerable oceanic variability has been detected at both seasonal and interannual timescales in front of both Pine Island (Webber et al., 2017) and Dotson Ice Shelf, located between Thwaites Glacier and Getz Ice Shelf, (Jenkins et al., 2018). It is driven by both local and remote forcing. Hence, we shall expect some differences between merged hydrographic observations and a simulated long-term mean, while a reliable climatological data set is lacking for our region of interest. Therefore, we use existing observations for comparison with our simulations under the assumption that available observations represent a quasi-mean state. Measured bottom temperatures, predominantly taken in austral summer by the marine cruises ANT XI/3 (Miller and Grobe, 1996) and ANT XXVI/3 (Gohl, 2010), confirm that the simulated bottom temperature distribution is reasonable (Fig. 1).

We investigate differences in ice shelf basal melting with (WALL) and without (CTRL) the erection of a wall surrounding the Amundsen Sea (Fig. 2a). This feature follows the approximate location of the continental shelf break and blocks any circulation below $350 \mathrm{~m}$ depth, such as the CDW inflow from the deep ocean onto the Amundsen Sea sector's continental shelf (Fig. 2). The wall proposed by Moore et al. (2018) blocks only the channelized flow of warm water in troughs leading directly to Pine Island and Thwaites glaciers, while our wall, with a length of about $800 \mathrm{~km}$, is substantially longer than the initially proposed wall in size and shields the entire Amundsen Sea embayment.

\section{Results}

Consistent with oceanographic observations, our CTRL experiment accurately simulates the ingress and delivery of warm mCDW through submarine troughs towards the ice shelves fringing the Amundsen Sea sector (Fig. 1). Measured bottom temperatures, acquired in austral summer, also strongly agree with the spatial distribution of our simulated temperatures, giving confidence in our abilities to accurately predict basal melting in the present study (Fig. 1).

Contrary to our CTRL experiment, our erected wall blocks the ocean below $350 \mathrm{~m}$ depth and suppresses the direct inflow of CDW to the interior of the Amundsen Sea embayment in front of western Marie Byrd Land. Consequently, the simulated ocean is generally cooler (Fig. 2a) and fresher within the walled region. This colder water column supports enhanced sea ice formation, which releases brine into the underlying ocean across this region. However, the brineinduced salinification is insufficient to compensate for the salinity supply of the unobstructed mCDW inflow.

We also detect a slight cooling of the bottom temperatures east of the walled region. The outflow of cooler water masses from the walled region via the Abbot Ice Shelf's sub-ice-shelf cavity (south of Thurston Island) contributes to this cooling (Fig. 2a and b). The deflected warm water mass flows westward and raises the temperature on the west side of the walled region. This causes the temperature to rise in the westernmost corner of the walled region around Siple Island because the warm water mass penetrates via the Getz Ice Shelf (between the grounding line of Antarctica and Siple Island) into the walled region.

In the walled region, the lower ocean temperature reduces the melting of ice shelves (Fig. 2a and c). However, the restrained warm water mass advances into the neighboring region, where ice shelves experience intensified melting and amplified ice mass loss (central and western Getz Ice Shelf; Fig. 2b). Therefore, the warm water mass that would have otherwise impacted the Amundsen Sea embayment, shifts to neighboring ice shelves.

Figure 3 depicts the longitudinal distribution of the simulated basal melting rates around Antarctica, with and without erection of the submarine wall. In the Amundsen Sea embayment the ice mass loss around Pine Island drops significantly (by $85 \%$ ). This phenomenon contrasts with increased ice mass loss detected at Getz Ice Shelf $\left(\sim 130^{\circ} \mathrm{W}\right.$, eastern Marie Byrd Land), where melting increases by approximately $50 \%$. As discussed above, basal melting is reduced in the western Bellingshausen Sea. In addition to the decreased melting simulated underneath the Abbot Ice Shelf, basal melting at George VI Ice Shelf increases by up to $10 \%$. The wall has little impact on basal melting of ice shelves fed by ice streams from the East Antarctic Ice Sheet, except for the Amery Ice Shelf, where the rate increases by approximately $5 \%$. The wall in the Amundsen Sea most probably triggers a perturbation that propagates via the Antarctic Coastal Current towards the Prydz Bay in front of the Amery Ice Shelf. All the above-reported intensified melting rates are larger than the standard deviation $(1-\sigma)$ of the 20 -year melting rate.

Besides regional changes in the basal melting rates, we inspect the continent-wide integrated effect. The reduced ice loss in the Amundsen Sea embayment is larger than the corresponding enhanced melting at the western end of the wall. The total ice loss by ice shelves around Antarctica is $10 \%$ lower for the WALL experiment.

\section{Conclusions}

In this study, a submarine wall erected along the continental shelf of the Amundsen Sea is found to suppress the inflow of Circumpolar Deep Water onto the continental shelf. This freshens and cools water masses residing shoreward of the wall, resulting in significantly reduced basal melting rates of the ice shelves located there. However, inflowing warm Circumpolar Deep Water (CDW) seaward of this wall is found to be redirected westward towards Getz Ice Shelf, where it enhances basal melting by up to $50 \%$. In particular, the ice shelves to the west (central and west Getz Ice Shelf) show steeply increased melting rates. Hence, the wall reduces the ice loss of the most vulnerable ice shelves along the mar- 

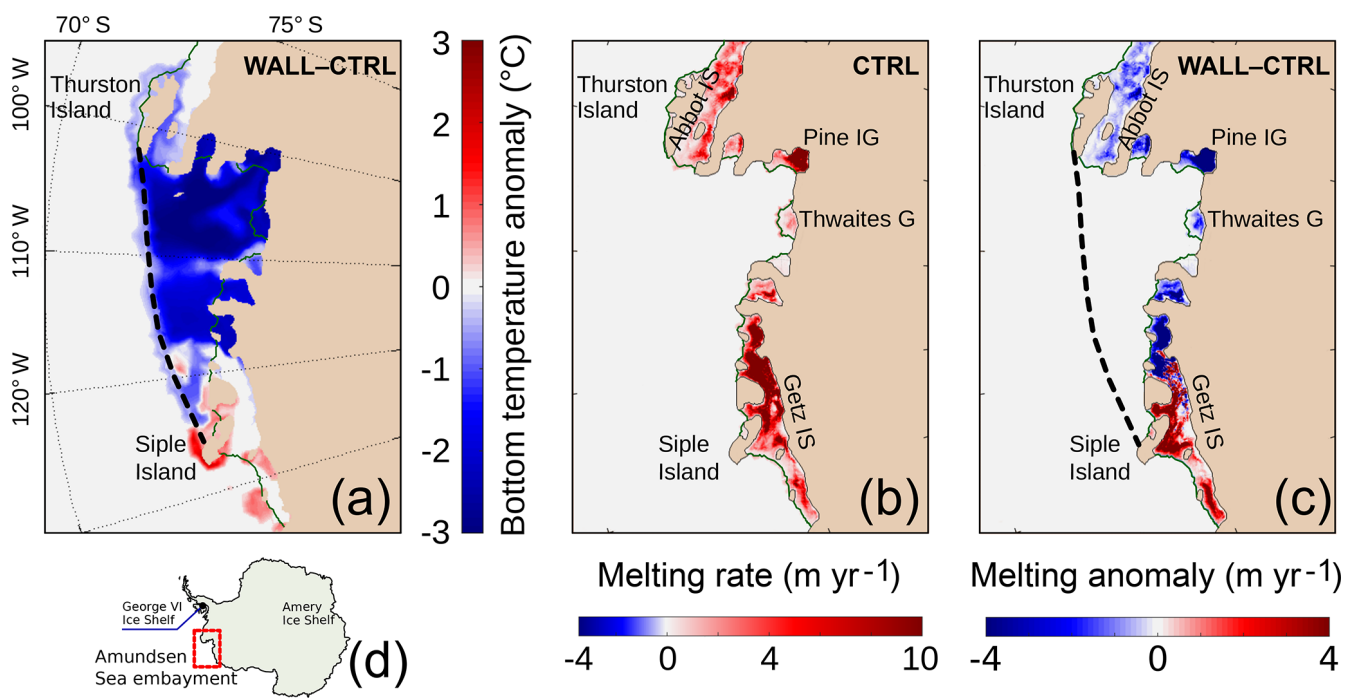

Figure 2. Simulated potential ocean temperature anomaly (WALL-CTRL) (a) and simulated basal ice shelf melting rates (CTRL) in (b) and its anomaly (c). Panel (a) shows the simulated potential ocean temperature anomaly (WALL-CTRL) on the seafloor of the Amundsen Sea embayment and its adjacent ice shelf cavities. The location of the wall is marked as a dashed line, and the embayment region is defined in the map (d). Panel (b) shows the simulated melting rates for the control run (CTRL), and panel (c) shows the basal melting anomaly (WALL - CTRL). Solid green lines highlight ice shelf edges. The following abbreviations are used: Abbot IS (Abbot Ice Shelf), Pine IG (Pine Island Glacier), Thwaites G (Thwaites Glacier) and Getz IS (Getz Ice Shelf).

gin of the West Antarctic Ice Sheet, which is, however, not compensated for by enhanced melting in the west. Integrated over Antarctica, the wall decreases ice loss by $10 \%$. Our results indicate that suppressing the flow of warm water masses into a restricted group of ice shelves results in redirecting it towards a different location. There it enhances basal melting and, ultimately, amplifies ice mass loss. However, it is an open question if this triggers marine ice sheet instability in the other shelves because the stability depends strongly on the distribution of pinning points, sloping of the bed, the depth and width of submarine troughs, and the softness of the bed. The onshore bed properties of eastern Marie Byrd Land, where Pine Island and Thwaites glaciers are located, are most likely vulnerable to the marine ice sheet instability. Numerous modeling studies show a relic ice cap in western Marie Byrd Land on the elevated bedrock topography, even after part of the West Antarctic Ice Sheet (WAIS) has collapsed (e.g., DeConto and Pollard, 2016; Feldmann and Levermann, 2015; Golledge et al., 2015; Winkelmann et al., 2015). Hence, western Marie Byrd Land is favorable for a stable situation. However, the bed properties under the ice are still insufficiently known.

Our fully coupled sea ice-ocean model, which includes ice shelves and ocean-ice shelf interaction, is driven by a prescribed atmospheric forcing. Hence, any feedbacks, such as changing ocean surface conditions that impact the atmosphere and change the atmospheric forcing on the ocean, are not included. Therefore, small anomalies between both simulations (CTRL vs. WALL), such as those seen on George VI Ice Shelf or in Prydz Bay in front of Amery Ice Shelf, could vanish if we included atmosphere-ocean feedbacks. Here only simulations coupled to the atmosphere would allow for confirming the robustness of these features.

The used bedrock topography and ice shelf geometry data set influences the melting rate of individual ice shelf caverns, as it has been shown for the smaller Crosson and Dotson ice shelves, which also drain into the Amundsen Sea (Goldberg et al., 2019). Hence, the most updated data sets would be preferred; however, existing inconsistencies between the most updated data sets, which are seen in differences of the reported grounding positions, freeboard heights, and bedrock elevation, require the use of data products, such as RTOPO. Therefore, we use RTOPO instead of the most updated products. Since our simulations are consistent with prior studies using RTOPO, the quality of our simulations could be judged in the light of previous studies.

Would we detect the penetration of warm water masses via the Getz Ice Shelf into the walled region if we used other bathymetry or bedrock topography data sets? If all ice were grounded between the western end of the wall and the coastline, we would not see any flow of warm water into the walled region. However, we would detect enhanced melting, which may open up a route into the protected region. Hence, fully coupled ice sheet-ocean model simulations, where the geometry of ice shelves are changed by melting and refreezing, would reveal the vulnerability of the Getz Ice Shelf. These simulations could also uncover if enhanced melting at the western end of the wall unlocks a back door that opens a second route to the ice shelves prone to marine ice sheet instability. 


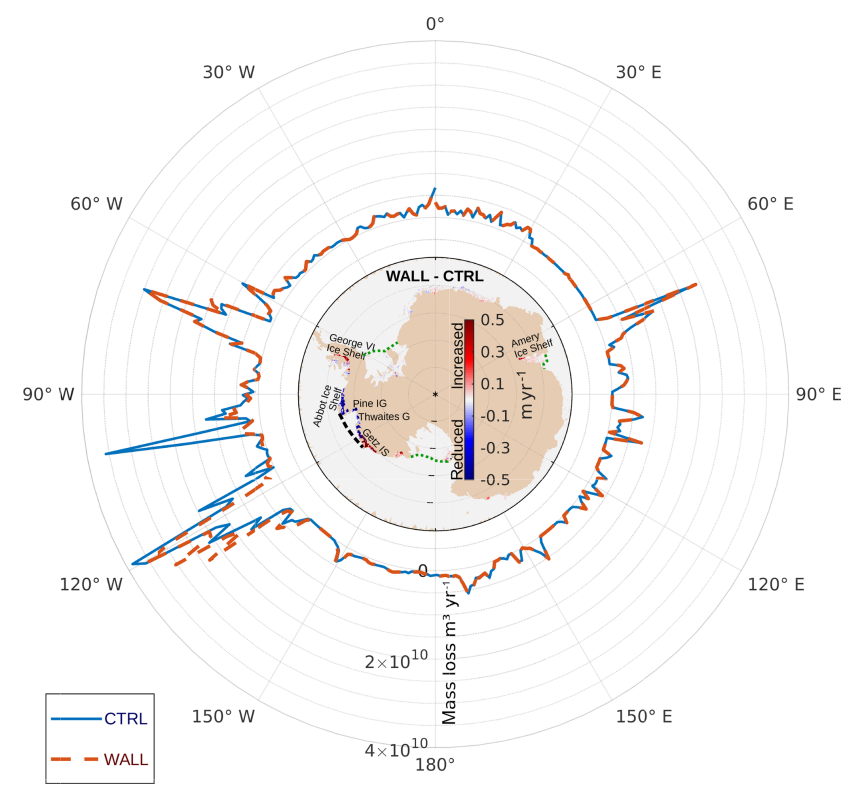

Figure 3. Mean basal melting rates around Antarctica. Longitudespecific changes in modeled basal melting with (WALL) and without (CTRL) the presence of the submarine wall are shown as dashed red and solid blue lines surrounding the center map, respectively. The dashed black line marks the wall's location in the Amundsen Sea. The map of Antarctica shows the spatial distribution of the melting rate anomaly, where positive numbers (red color) represent increased melting rates if the wall is present (see color bar). The following abbreviations are used: Pine IG (Pine Island Glacier), Thwaites G (Thwaites Glacier) and Getz IS (Getz Ice Shelf). Dotted green lines depict shelf ice edges of the Ross Ice Shelf, the FilchnerRonne Ice Shelf and the Amery Ice Shelf.

Regardless of the bathymetry data set used, we are confident that the main findings of this study are robust: a wall shielding the Amundsen Sea embayment reduces basal melting rates within the protected region, the rejected warm water masses flow along the wall westward, west of the wall warmer water masses drive enhanced basal melting. The wall proposed by Moore et al. (2018), which blocks only the circulation in troughs leading directly to Pine Island and Thwaites glaciers, would have a length of about $50-100 \mathrm{~km}$ and would need $10-50 \mathrm{~km}^{3}$ of material. By comparison, the construction of the Suez Canal required the excavation of about $1 \mathrm{~km}^{2}$ of material (Moore et al., 2018). The simulated wall (length of about $800 \mathrm{~km}$ ) is substantially larger than the initially proposed wall in size and shields the entire Amundsen Sea embayment.

Our results suggest that a too-small wall, for instance, blocking only the water flow in the troughs leading to Pine Island might be bypassed by warm water masses. For dynamical reasons, the (geostrophic) flow of water masses turns to the left (in the Southern Hemisphere) if it is not hindered by a topographic obstacle. Therefore, warm water masses might even recirculate into the ostensibly protected area if the wall is too small, as the inflow of warm water masses through the Getz Ice Shelf into the walled region suggests. However, a small wall that only protects Pine Island successfully may redirect the warm water to neighboring ice shelves with a retrograde bed (for example, Thwaites Glacier). There it increases basal melting and may trigger marine ice sheet instability. The detected poleward shift of westerly winds in the Southern Ocean under global warming (Miller et al., 2006) might also shift easterly winds along Antarctica's coast poleward, which lifts further the interface of warm water masses (isothermal) along the continental slope (Spence et al., 2014). Ultimately warm water masses could enter the continental shelf directly beside the contemporary path following topographic depressions (troughs). Under these circumstances, the bypassing of a short wall seems to be inevitable if the wall does not block the entire Amundsen Sea embayment from coast to coast.

Iron is a micronutrient essential for algal production in the Amundsen Sea (St-Laurent et al., 2017) and the erected wall affects its availability. The wall blocks in the inflow of warm and iron-rich CDW and influences the outflow of iron-rich glacial meltwater coming from melting ice shelves. How the changed nutrient supply impacts the marine biological web or the uptake and sequestration of carbon dioxide by the ocean is unclear and goes beyond this study.

Geoengineering aims to attenuate the impact of the ongoing anthropogenic climate change, such as sea level rise, but the results of this study suggest that such proposals could have adverse side effects. To evaluate the effects of using submarine walls to protect Antarctica's ice shelves in greater detail, the use of fully coupled ice-sheet-ice-shelf-oceanatmosphere models should be utilized in future analyses. These models of sufficiently high spatial resolution could accurately simulate changes in sub-ice-shelf cavity geometry (including track grounding line migration and ice shelf thinning) as well as the influx of warm water masses (mCDW) to these locations.

Code and data availability. The FESOM1.4 model code is available at https://swrepo1.awi.de/projects/fesom/ (last access: 4 September 2019), after registration. The atmospheric forcing data set named "CORE-II" used here (Large and Yeager, 2008) is freely accessible online at https://data1.gfdl.noaa. gov/nomads/forms/core/COREv2.html (last access: 4 September 2019). The topography data set RTOPO can be obtained from https://doi.org/10.1594/PANGAEA.741917 (Timmermann et al., 2010). The temporal average of the fractional basal melting changes between the CTRL and WALL simulations is obtainable from Zenodo via https://doi.org/10.5281/zenodo.3240250 (Gürses et al., 2019). The remaining data is available from the first author Özgür Gürses upon reasonable request. 
Author contributions. CR designed the study and wrote the manuscript. ÖG and QW developed and configured the model. ÖG ran the simulations. ÖG and VK performed the analysis. VK and $\mathrm{CR}$ prepared the figures. All authors contributed to the interpretation of the results and proofreading of the manuscript.

Competing interests. The authors declare that they have no conflict of interest.

Acknowledgements. We thank Evan Gowan in particular for his comments, which greatly improved this paper. We thank both anonymous reviewers and Mike Wolovick for their comments and engagement in the review process, which improved the manuscript.

Financial support. This research has been supported by the German Federal Ministry of Education and Research (Bundesministerium für Bildung und Forschung, BMBF, grant no. 01LS1612A).

The article processing charges for this open-access publication were covered by a Research

Centre of the Helmholtz Association.

Review statement. This paper was edited by Benjamin Smith and reviewed by two anonymous referees.

\section{References}

Bamber, J. L., Riva, R. E. M., Vermeersen, B. L. A., and LeBrocq, A. M.: Reassessment of the potential sea-level rise from a collapse of the West Antarctic Ice Sheet, Science, 324, 901-903, https://doi.org/10.1126/science.1169335, 2009.

Bingham, R. G., Ferraccioli, F., King, E. C., Larter, R. D., Pritchard, H. D., Smith, A. M., and Vaughan, D. G.: Inland thinning of West Antarctic Ice Sheet steered along subglacial rifts, Nature, 487, 468-471, https://doi.org/10.1038/nature11292, 2012.

Chen, X., Zhang, X., Church, J. A., Watson, C. S., King, M. A., Monselesan, D., Legresy, B., and Harig, C.: The increasing rate of global mean sea-level rise during 1993-2014, Nat. Clim. Change, 7, 492-495, https://doi.org/10.1038/nclimate3325, 2017.

DeConto, R. M. and Pollard, D.: Contribution of Antarctica to past and future sea-level rise, Nature, 531, 591-597, https://doi.org/10.1038/nature17145, 2016.

Depoorter, M., Bamber, J. L., Griggs, J. A., Lenaerts, J. T. M., Ligtenberg, S. R. M., van den Broeke, M. R., and Moholdt, G.: Calving fluxes and basal melt rates of Antarctic ice shelves, Nature, 502, 89-92, https://doi.org/10.1038/nature12567, 2013.

Dutrieux, P., De Rydt, J., Jenkins, A., Holland, P. R., Ha, H. K., Lee, S. H., Steig, E. J., Ding, Q., Abrahamsen, E. P., and Schröder, M.: Strong Sensitivity of Pine Island IceShelf Melting to Climatic Variability, Science, 174, 174-178, https://doi.org/10.1126/science.1244341, 2014.
Feldmann, J. and Levermann, A.: Collapse of the West Antarctic Ice Sheet after local destabilization of the Amundsen Basin, P. Natl. Acad. Sci. USA, 112, 14191-14196, https://doi.org/10.1073/pnas.1512482112, 2015.

Fretwell, P., Pritchard, H. D., Vaughan, D. G., Bamber, J. L., Barrand, N. E., Bell, R., Bianchi, C., Bingham, R. G., Blankenship, D. D., Casassa, G., Catania, G., Callens, D., Conway, H., Cook, A. J., Corr, H. F. J., Damaske, D., Damm, V., Ferraccioli, F., Forsberg, R., Fujita, S., Gim, Y., Gogineni, P., Griggs, J. A., Hindmarsh, R. C. A., Holmlund, P., Holt, J. W., Jacobel, R. W., Jenkins, A., Jokat, W., Jordan, T., King, E. C., Kohler, J., Krabill, W., Riger-Kusk, M., Langley, K. A., Leitchenkov, G., Leuschen, C., Luyendyk, B. P., Matsuoka, K., Mouginot, J., Nitsche, F. O., Nogi, Y., Nost, O. A., Popov, S. V., Rignot, E., Rippin, D. M., Rivera, A., Roberts, J., Ross, N., Siegert, M. J., Smith, A. M., Steinhage, D., Studinger, M., Sun, B., Tinto, B. K., Welch, B. C., Wilson, D., Young, D. A., Xiangbin, C., and Zirizzotti, A.: Bedmap2: improved ice bed, surface and thickness datasets for Antarctica, The Cryosphere, 7, 375-393, https://doi.org/10.5194/tc-7-375-2013, 2013.

Gohl, K.: The Expedition of the Research Vessel "Polarstern" to the Amundsen Sea, Antarctica, in 2010 (ANT-XXVI/3), Bremerhaven, Germany, available at: http://hdl.handle.net/10013/epic. 35668 (last access: 11 December 2018), 2010.

Goldberg, D. N., Gourmelen, N., Kimura, S., Millan, R., and Snow, K.: How Accurately Should We Model Ice Shelf Melt Rates?, Geophys. Res. Lett., 46, 189-199, https://doi.org/10.1029/2018GL080383, 2019.

Golledge, N. R., Levy, R. H., McKay, R. M., Fogwill, C. J., White, D. A., Graham, A. G. C., Smith, J. A., Hillenbrand, C. D., Licht, K. J., Denton, G. H., Ackert, R. P., Maas, S. M., and Hall, B. L.: Glaciology and geological signature of the Last Glacial Maximum Antarctic ice sheet, Quaternary Sci. Rev., 78, 225-247, https://doi.org/10.1016/j.quascirev.2013.08.011, 2013.

Golledge, N. R., Kowalewski, D. E., Naish, T. R., Levy, R. H., Fogwill, C. J., and Gasson, E. G. W.: The multi-millennial Antarctic commitment to future sea-level rise, Nature, 526, 421-425, https://doi.org/10.1038/nature15706, 2015.

Gürses, Ö., Kolatschek, V., Wang, Q., and Rodehacke, C. B.: Brief communication: A submarine wall protecting the Amundsen Sea intensifies melting of neighboring ice shelves, Zenodo https://doi.org/10.5281/zenodo.3240250, 2019.

Hellmer, H. H. and Olbers, D. J.: A two-dimensional model for the thermohaline circulation under an ice shelf, Antarct. Sci., 1, 325336, https://doi.org/10.1017/S0954102089000490, 1989.

Hellmer, H. H., Kauker, F., Timmermann, R., Determann, J., and Rae, J.: Twenty-first-century warming of a large Antarctic iceshelf cavity by a redirected coastal current, Nature, 485, 225228, https://doi.org/10.1038/nature11064, 2012.

Holland, D. M. and Jenkins, A.: Modeling Thermodynamic Ice-Ocean Interactions at the Base of an Ice Shelf, J. Phys. Oceanogr., 29, 1787-1800, https://doi.org/10.1175/15200485(1999)029<1787:MTIOIA>2.0.CO;2, 1999.

Jacobs, S. S., Jenkins, A., Giulivi, C. F., and Dutrieux, P.: Stronger ocean circulation and increased melting under Pine Island Glacier ice shelf, Nat. Geosci., 4, 519-523, https://doi.org/10.1038/ngeo1188, 2011.

Jenkins, A., Shoosmith, D., Dutrieux, P., Jacobs, S., Kim, T. W., Lee, S. H., Ha, H. K., and Stammerjohn, S.: West 
Antarctic Ice Sheet retreat in the Amundsen Sea driven by decadal oceanic variability, Nat. Geosci., 11, 733-738, https://doi.org/10.1038/s41561-018-0207-4, 2018.

Joughin, I. and Alley, R. B.: Stability of the West Antarctic ice sheet in a warming world, Nat. Geosci., 4, 506-513, https://doi.org/10.1038/ngeo1194, 2011.

Kim, T. W., Ha, H. K., Wåhlin, A. K., Lee, S. H., Kim, C. S., Lee, J. H., and Cho, Y. K.: Is Ekman pumping responsible for the seasonal variation of warm circumpolar deep water in the Amundsen Sea?, Cont. Shelf Res., 132, 38-48, https://doi.org/10.1016/j.csr.2016.09.005, 2017.

King, M. A., Bingham, R. J., Moore, P., Whitehouse, P. L., Bentley, M. J., and Milne, G. A.: Lower satellite-gravimetry estimates of Antarctic sea-level contribution, Nature, 491, 586-589, https://doi.org/10.1038/nature11621, 2012.

Large, W. G. and Yeager, S. G.: The global climatology of an interannually varying air-sea flux data set, Clim. Dynam., 33, 341364, https://doi.org/10.1007/s00382-008-0441-3, 2008.

Miller, H. and Grobe, H.: Die Expedition ANTARKTIS-XI/3 mit FS "Polarstern" 1994 (engl. The Expedition ANTARKTIS-XI/3 of RV "Polarstern" in 1994), Bremerhaven, Germany, available at: http://epic.awi.de/26366/1/10189.pdf (last access: 11 December 2018), 1996.

Miller, R. L., Schmidt, G. A., and Shindell, D. T.: Forced annular variations in the 20th century Intergovernmental Panel on Climate Change Fourth Assessment Report models, J. Geophys. Res., 111, D18101, https://doi.org/10.1029/2005JD006323, 2006.

Moore, J. C., Gladstone, R., Zwinger, T., and Wolovick, M.: Geoengineer polar glaciers to slow sea-level rise, Nature, 555, 303305, https://doi.org/10.1038/d41586-018-03036-4, 2018.

Nakayama, Y., Timmermann, R., Rodehacke, C. B., Schröder, M., and Hellmer, H. H.: Modeling the spreading of glacial melt water from the Amundsen and Bellingshausen Seas, Geophys. Res. Lett., 41, 7942-7949, https://doi.org/10.1002/2014GL061600, 2014.

Nakayama, Y., Menemenlis, D., Zhang, H., Schodlok, M., and Rignot, E.: Origin of Circumpolar Deep Water intruding onto the Amundsen and Bellingshausen Sea continental shelves, Nat. Commun., 9, 3403, https://doi.org/10.1038/s41467-018-05813$1,2018$.

Naughten, K. A., Meissner, K. J., Galton-Fenzi, B. K., England, M. H., Timmermann, R., Hellmer, H. H., Hattermann, T., and Debernard, J. B.: Intercomparison of Antarctic iceshelf, ocean, and sea-ice interactions simulated by MetROMSiceshelf and FESOM 1.4, Geosci. Model Dev., 11, 1257-1292, https://doi.org/10.5194/gmd-11-1257-2018, 2018.

Paolo, F. S., Padman, L., Fricker, H. A., Adusumilli, S., Howard, S., and Siegfried, M. R.: Response of Pacific-sector Antarctic ice shelves to the El Niño/Southern Oscillation, Nat. Geosci., 11, 121-126, https://doi.org/10.1038/s41561-017-0033-0, 2018.

Pollard, D. and DeConto, R. M.: Modelling West Antarctic ice sheet growth and collapse through the past five million years., Nature, 458, 329-332, https://doi.org/10.1038/nature07809, 2009.

Pritchard, H. D., Ligtenberg, S. R. M., Fricker, H. A., Vaughan, D. G., van den Broeke, M. R., and Padman, L.: Antarctic ice-sheet loss driven by basal melting of ice shelves, Nature, 484, 502-505, https://doi.org/10.1038/nature10968, 2012.
Rietbroek, R., Brunnabend, S.-E., Kusche, J., Schröter, J., and Dahle, C.: Revisiting the contemporary sea-level budget on global and regional scales, P. Natl. Acad. Sci. USA, 113, 15041509, https://doi.org/10.1073/pnas.1519132113, 2016.

Rignot, E., Velicogna, I., van den Broeke, M. R., Monaghan, A., and Lenaerts, J.: Acceleration of the contribution of the Greenland and Antarctic ice sheets to sea level rise, Geophys. Res. Lett., 38, 1-5, https://doi.org/10.1029/2011GL046583, 2011.

Rignot, E., Jacobs, S., Mouginot, J., and Scheuchl, B.: IceShelf Melting Around Antarctica, Science, 341, 266-270, https://doi.org/10.1126/science.1235798, 2013.

Rignot, E., Mouginot, J., Morlighem, M., Seroussi, H., and Scheuchl, B.: Widespread, rapid grounding line retreat of Pine Island, Thwaites, Smith, and Kohler glaciers, West Antarctica, from 1992 to 2011, Geophys. Res. Lett., 41, 3502-3509, https://doi.org/10.1002/2014GL060140, 2014.

Schmidt, H., Rast, S., Bunzel, F., Esch, M., Giorgetta, M., Kinne, S., Krismer, T., Stenchikov, G., Timmreck, C., Tomassini, L., and Walz, M.: Response of the middle atmosphere to anthropogenic and natural forcings in the CMIP5 simulations with the Max Planck Institute Earth system model, J. Adv. Model. Earth Syst., 5, 98-116, https://doi.org/10.1002/jame.20014, 2013.

Schoof, C.: Marine ice-sheet dynamics. Part 1. The case of rapid sliding, J. Fluid Mech., 573, 27-55, https://doi.org/10.1017/S0022112006003570, 2007.

Shepherd, A., Ivins, E. R., Geruo, A., Barletta, V. R., Bentley, M. J., Bettadpur, S., Briggs, K. H., Bromwich, D. H., Forsberg, R., Galin, N., Horwath, M., Jacobs, S., Joughin, I., King, M. A., Lenaerts, J. T. M., Li, J., Ligtenberg, S. R. M., Luckman, A., Luthcke, S. B., McMillan, M., Meister, R., Milne, G., Mouginot, J., Muir, A., Nicolas, J. P., Paden, J., Payne, A. J., Pritchard, H., Rignot, E., Rott, H., Sorensen, L. S., Scambos, T. A., Scheuchl, B., Schrama, E. J. O., Smith, B., Sundal, A. V., van Angelen, J. H., van de Berg, W. J., van den Broeke, M. R., Vaughan, D. G., Velicogna, I., Wahr, J., Whitehouse, P. L., Wingham, D. J., Yi, D., Young, D., and Zwally, H. J.: A Reconciled Estimate of Ice-Sheet Mass Balance, Science, 338, 1183-1189, https://doi.org/10.1126/science.1228102, 2012.

Shepherd, A., Fricker, H. A., and Farrell, S. L.: Trends and connections across the Antarctic cryosphere, Nature, 558, 223-232, https://doi.org/10.1038/s41586-018-0171-6, 2018.

Spence, P., Griffies, S. M., England, M. H., Hogg, A. M., Saenko, O. A., and Jourdain, N. C.: Rapid subsurface warming and circulation changes of Antarctic coastal waters by poleward shifting winds, Geophys. Res. Lett., 41, 4601-4610, https://doi.org/10.1002/2014GL060613, 2014.

St-Laurent, P., Yager, P. L., Sherrell, R. M., Stammerjohn, S. E., and Dinniman, M. S.: Pathways and supply of dissolved iron in the Amundsen Sea (Antarctica), J. Geophys. Res.-Ocean, 122, 7135-7162, https://doi.org/10.1002/2017JC013162, 2017.

Steig, E. J., Ding, Q., Battisti, D. S., and Jenkins, A.: Tropical forcing of Circumpolar Deep Water Inflow and outlet glacier thinning in the Amundsen Sea Embayment, West Antarctica, Ann. Glaciol., 53, 19-28, https://doi.org/10.3189/2012AoG60A110, 2012.

Sutter, J., Gierz, P., Grosfeld, K., Thoma, M., and Lohmann, G.: Ocean temperature thresholds for Last Interglacial West Antarctic Ice Sheet collapse, Geophys. Res. Lett., 43, 2675-2682, https://doi.org/10.1002/2016GL067818, 2016. 
Timmermann, R., Le Brocq, A., Deen, T., Domack, E., Dutrieux, P., Galton-Fenzi, B., Hellmer, H., Humbert, A., Jansen, D., Jenkins, A., Lambrecht, A., Makinson, K., Niederjasper, F., Nitsche, F., Nøst, O. A., Smedsrud, L. H., and Smith, W. H. F.: A consistent data set of Antarctic ice sheet topography, cavity geometry, and global bathymetry, Earth Syst. Sci. Data, 2, 261-273, https://doi.org/10.5194/essd-2-261-2010, 2010.

Timmermann, R., Wang, Q., and Hellmer, H. H.: Iceshelf basal melting in a global finite-element seaice/ice-shelf/ocean model, Ann. Glaciol., 53, 303-314, https://doi.org/10.3189/2012AoG60A156, 2012.

Timmermann, R., Le Brocq, A. M., Deen, T. J., Domack, E. W., Dutrieux, P., Galton-Fenzi, B., Hellmer, H. H., Humbert, A., Jansen, D., Jenkins, A., Lambrecht, A., Makinson, K., Niederjasper, F., Nitsche, F.-O., Nøst, O. A., Smedsrud, L. H., and Smith, W.: Antarctic ice sheet topography, cavity geometry, and global bathymetry (RTopo 1.0.5-beta). PANGAEA, https://doi.org/10.1594/PANGAEA.741917 (last access: 4 September 2019), Supplement to: Timmermann, R. et al. (2010): A consistent dataset of Antarctic ice sheet topography, cavity geometry, and global bathymetry, Earth Syst. Sci. Data, 2, 261-273, https://doi.org/10.5194/essd-2-261-2010, 2010.

Turner, J., Orr, A., Gudmundsson, G. H., Jenkins, A., Bingham, R. G., Hillenbrand, C. D., and Bracegirdle, T. J.: Atmosphere-ocean-ice interactions in the Amundsen Sea Embayment, West Antarctica, Rev. Geophys., 55, 235-276, https://doi.org/10.1002/2016RG000532, 2017.

Vaughan, D. G., Comiso, J. C., Allison, I., Carrasco, J., Kaser, G., Kwok, R., Mote, R., Murray, T., Paul, F., Rn, J., Rignot, E., Solomina, O., Steffen, K., and Zhang, T.: Observations: Cryosphere, in: Climate Change 2013: The Physical Science Basis. Contribution of Working Group I to the Fifth Assessment Report of the Intergovernmental Panel on Climate Change, edited by: Stocker, T. F., Qin, D., Plattner, G.-K., Tignor, M., Allen, S. K., Boschung, J., Nauels, A., Xia, Y., Bex, V., and Midgley, P. M., 66 pp., Cambridge University Press, Cambridge, UK and New York, NY, USA, available at: http://www.ipcc.ch/report/ar5/wg1/ (last access: 14 August 2018), 2013.
Wada, Y., van Beek, L. P. H., Sperna Weiland, F. C., Chao, B. F., $\mathrm{Wu}$, Y.-H., and Bierkens, M. F. P.: Past and future contribution of global groundwater depletion to sea-level rise, Geophys. Res. Lett., 39, L09402, https://doi.org/10.1029/2012GL051230, 2012.

Wang, Q., Danilov, S., Sidorenko, D., Timmermann, R., Wekerle, C., Wang, X., Jung, T., and Schröter, J.: The Finite Element Sea Ice-Ocean Model (FESOM) v.1.4: formulation of an ocean general circulation model, Geosci. Model Dev., 7, 663693, https://doi.org/10.5194/gmd-7-663-2014, 2014.

Webber, B. G. M., Heywood, K. J., Stevens, D. P., Dutrieux, P., Abrahamsen, E. P., Jenkins, A., Jacobs, S. S., Ha, H. K., Lee, S. H., and Kim, T. W.: Mechanisms driving variability in the ocean forcing of Pine Island Glacier, Nat. Commun., 8, 1-8, https://doi.org/10.1038/ncomms14507, 2017.

Webber, B. G. M., Heywood, K. J., Stevens, D. P., and Assmann, K. M.: The Impact of Overturning and Horizontal Circulation in Pine Island Trough on Ice Shelf Melt in the Eastern Amundsen Sea, J. Phys. Oceanogr., 49, 63-83, https://doi.org/10.1175/jpod-17-0213.1, 2018.

Weertman, J.: Stability of the junction of an ice sheet and an ice shelf, J. Glaciol., 13, 3-11, 1974.

Winkelmann, R., Levermann, A., Ridgwell, A., and Caldeira, K.: Combustion of available fossil fuel resources sufficient to eliminate the Antarctic Ice Sheet, Sci. Adv., 1, e1500589, https://doi.org/10.1126/sciadv.1500589, 2015.

Wolovick, M. J. and Moore, J. C.: Stopping the flood: could we use targeted geoengineering to mitigate sea level rise?, The Cryosphere, 12, 2955-2967, https://doi.org/10.5194/tc-12-29552018, 2018. 